\title{
STUDIES ON THE INFLUENCES OF HAYLURONIDASE AND DESOXYCO- RTICOSTERONE HCETATE TO RAT LEPROSY STUDIES ON THE RAT LEPROSY (21)
}

\author{
Ushio. Kiichi
}

Hiramoto Tuneki.

Department of Bacteriology, Hiroshima Medical College (Director : Prof.K. Urabe)

There had been examined the influences of hyaluronidase and desoxycorticosterone acetate to rat leprosy.

As the results, it was revieled that hyaluronidase accelerated the disseminatation of rat leprosy bacilli and promoted the rat leprous glanuroma, but not desoxycorticosterone acetate, comparaed with the controls.

(Arthors's abstract)

\section{ラッテ鼠獺に及ぼす Hyaluronidase 及び Desoxycorticosterone Acetate の影響}

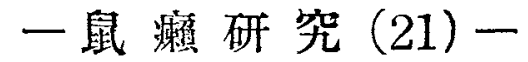

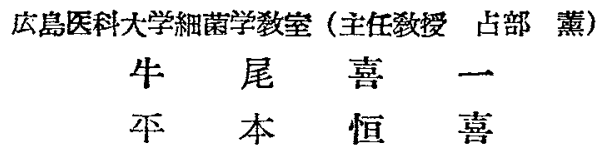

(この研究は文部省科学研究親によつた。なおこの要旨は昭和26年11月11日日本細菌学会第 4 回中国四国 地方会に括いて報告した。)

\section{粕言}

著者の 1 人牛尾(はは先にマウスを用いて Hyaluro-

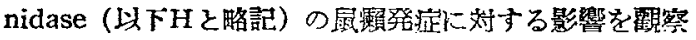
し，Hは鼠顽菌の体內播布を促進し日.H注射回数と諸藏 器への菌播布度とはほ心゙平行することを速べた。

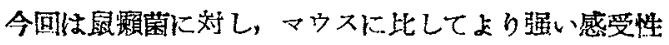
をもつラッテを用い高単位のHのしかも連続注射がその

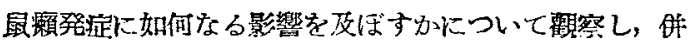
せて最近副婜皮質ホルモンの1種でるる Cortisone が 結核病変を悪化させるという Hart and Ress(2) 括よび Spain and Molomut(3)の報告があり，他方 Desoxycorticosterone Acetate (以下 DOCA 々略記) を Vitamine C と妍用すると関節口イマチスに対し Cortisone

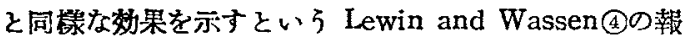

告があることに示唆を得て，今回は DOCA を単独に与

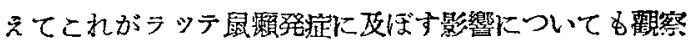
したので以下結果を報告する。

\section{蒀驗材料及び方法}

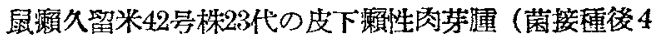
カ月）よりの約20掊生塩水乳剤 $0.5 \mathrm{cc}$ 宛を20匹のラッテ

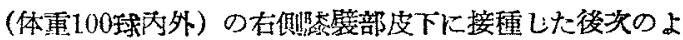
らに群放した。

動物群别：H洋一 -6 匹，DOCA群一 7 匹，生瑱水注射 対照群一 7 匹。

供試藥品：Hは持田製藥の Sprase を，またDOCA は武田燕工の Syncorta を使用した。

投蔡の量と方法 : 鼠制菌接璉感染翌日より各群とも投 


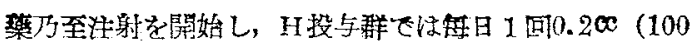

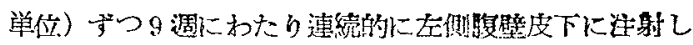

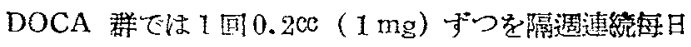
左右兩大腿部の解肉局に交互に注射し，また対熙群では

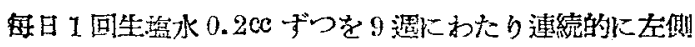
榎壁部皮下に注射した。

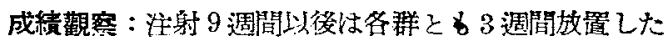

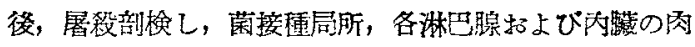

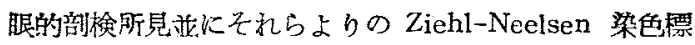

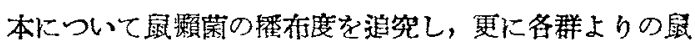
㭸菌についてその菌長，抗薏沸性，顆粒怙よび被染性を 夫々榆䒺した。

な呿ラッテ生存中心各週末に各動物の体重治よび外表 の沗化を賏察した。

成綪舦定基準：肉眠的所見では皮下颗性肉芽はその縰

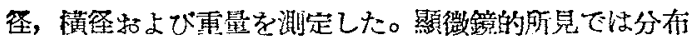
菌数拉よびグロービー数を Gaffky の莀に做つてつくつ た表1に示挷定基準により数値をるつて示したが，こ のちちグロービーの制定には，その大きさ前にそれに含 まれる菌数の多少により数㨁を変更した場合もあつた。

表 1 鼠瀨菌の分布度制定表

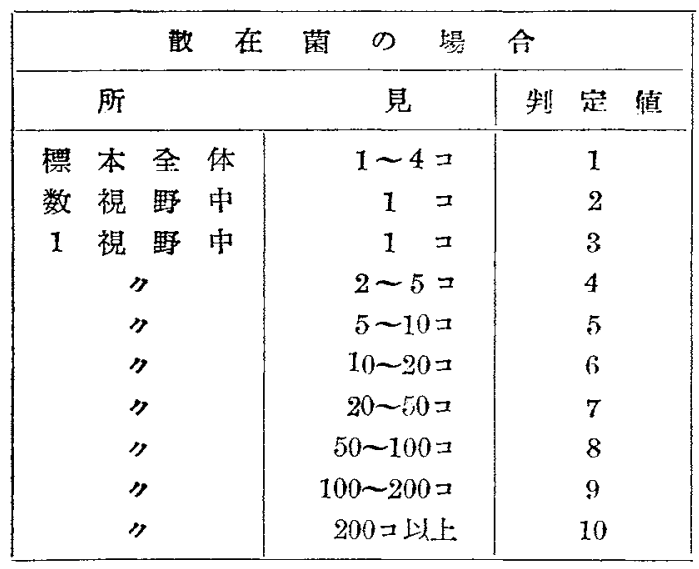

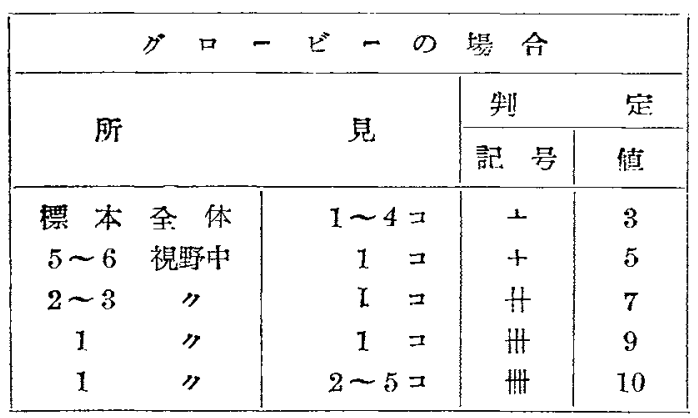

\section{實 驗 成 績}

実験成積の詳細については一括して表 2 に示した。

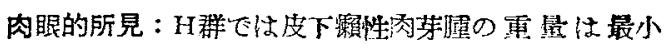
0.3 瓦, 最大 1.2 互でその平均雷壆は他の 2 群のそれと比 䩙して約2.5音も大であつた。DOCA 群では腹壁皮下に

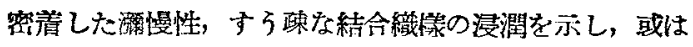
顀性肉芽結節を形成したものでも，その重監，大きさ共 に対然群のそれと比較すると僅かながら小さかつた。各

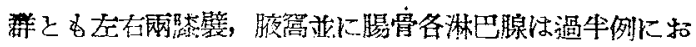

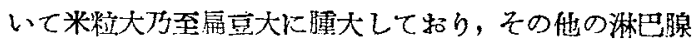
にす稍鄠大が見られる場合もあつた。そして一般にいつ

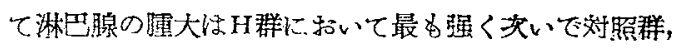
DOCA 群の順のよろに見らけられた。但し淋巴腺の埂

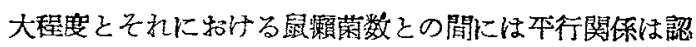
女難かつた。

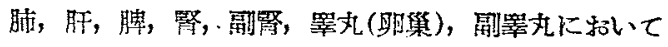
は各群共肉限的䃌化は認めなかつた。

顥微镜的所見: 菌の形態的所見では, 菌長はH群が本 均 $1.82 \mu$ ，DOCA群は $1.81 \mu ，$ 対照群は $1.77 \mu$ であり，

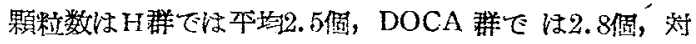

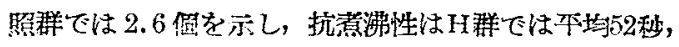
DOC4 群では50秒，站照群ては51秒であつた。即ち菌 長，顆粒数並に抗澺沸性に特いては各群を通して特記す べき著明な差異は認められなかつた。

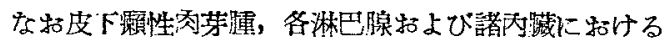

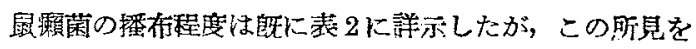
棇辞してヒストグラムに示すと図1のよろになる。

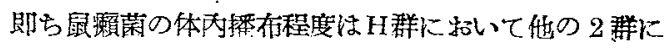

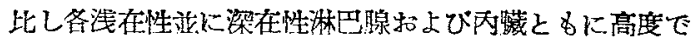
あつた。これに反し DOCA 群では対照群より稍低い菌 㩲有程度省分した。

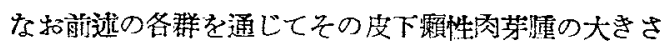
と菌篦有程度との間に本行関係のみられなかつたことは この図1によつても籍兄る。

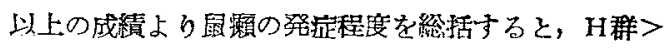
対照群> DOCA 群の順となる。

一般症狀：DOCA群は注射第4 日頃上り㱠んど䒩例港

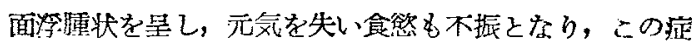

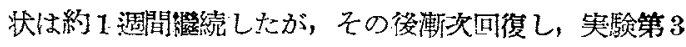

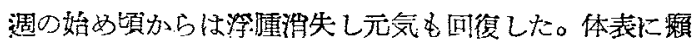
性彸化の山現は各群ともに見られなからた。

体重の撨移は一䑩して図2に亦した。

図 2 К見るよ5にDOCA 群は他の 2 群に比較して特 に第 1 遇に特ける叠加か㵔明て，第 4 週より第 6 週にか 
趇 2

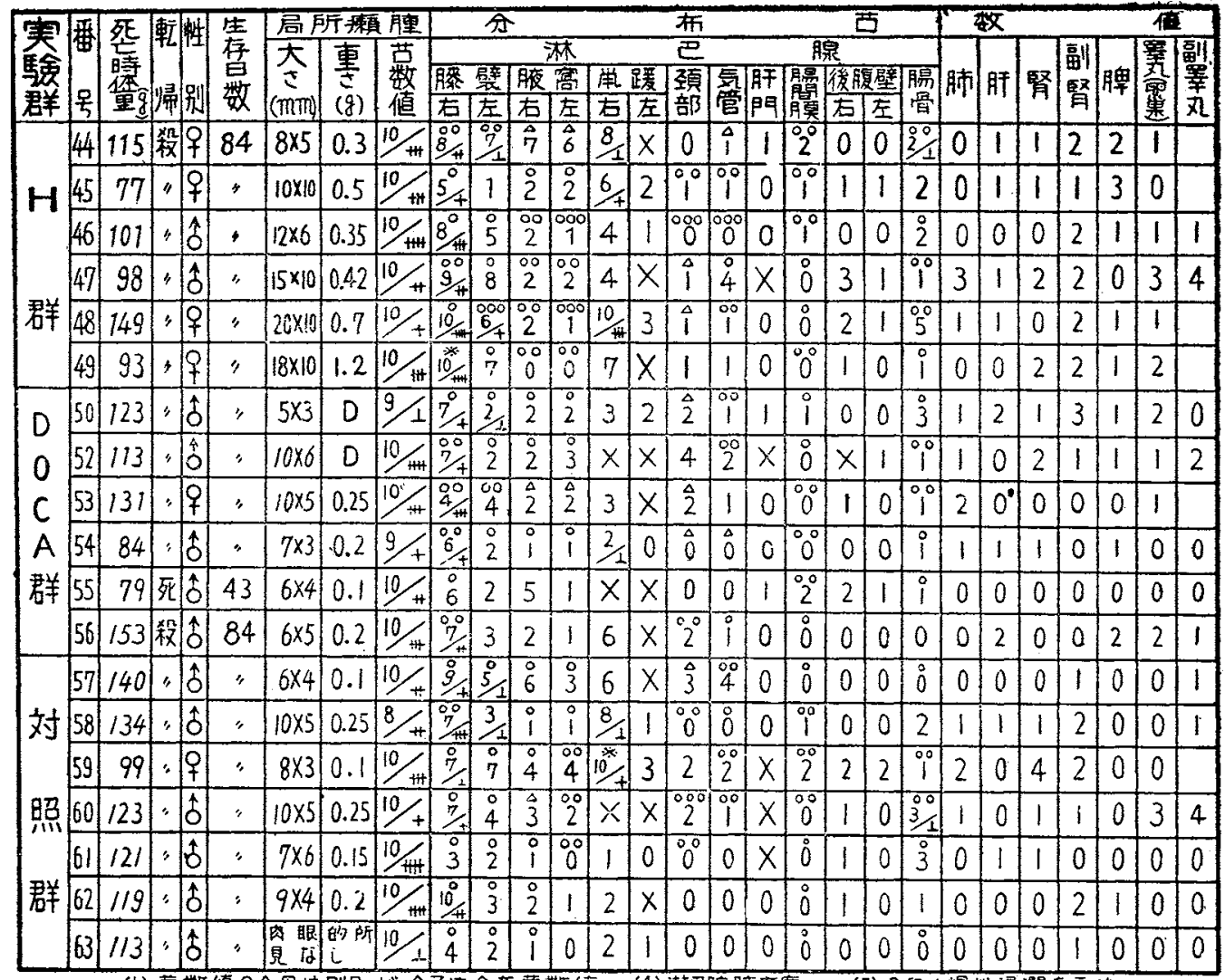

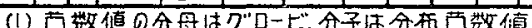

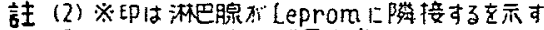

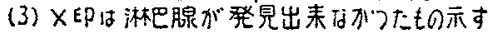

。半米社大, $\Delta$ 满豆大

○。米粠大,

000米粒大より大きく席昰大より小

圖 1

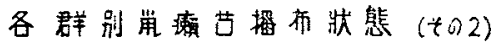

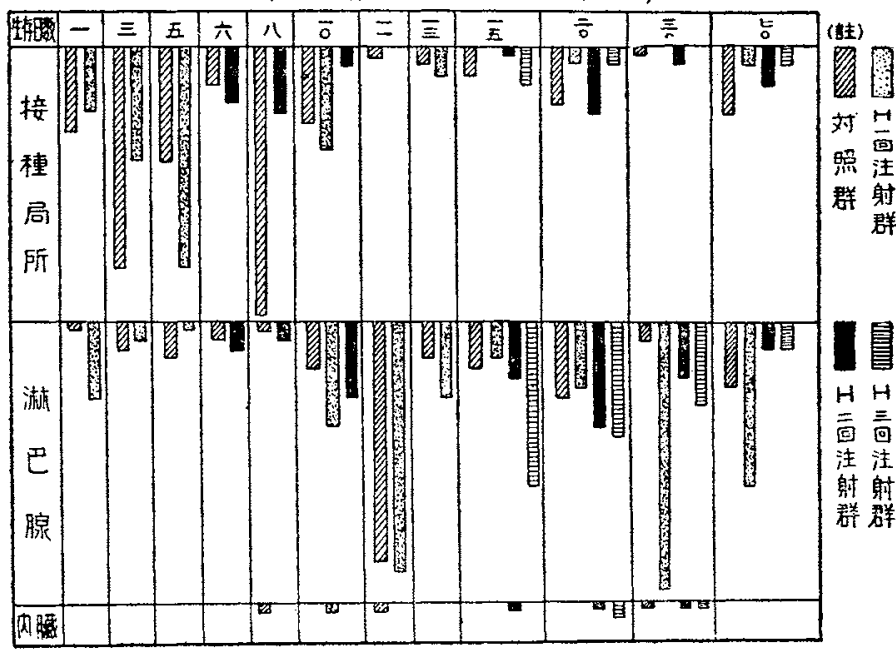




\section{圆2各群体重曲線}

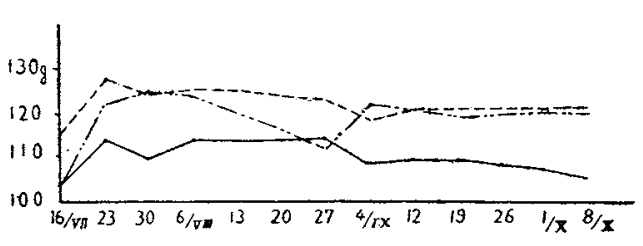

(a)

けて減少し，第7圈洅び增加を示したが，その後は他 の2群とほぶ類㑭の曲線を示した。H群は対照群によく

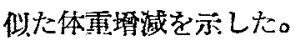

\section{總括並に考按}

前回(1マウスを用いてのHの鼠嬾に及战す影響につい

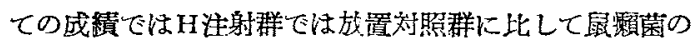
播布度が大であり，H注射群の各々においてはH注射回 数の叠加につれて菌接種部皮下に招ける菌数に淢少が見 られるに反し，各淋巴腺，諸内藏への菌播布度は墂加す ることが認められた。それはそれとして他す Corper and Cohn(B)に上るとHの皮下注射は結核動物に対して 何等の影響を及ぼさず，その稍高単位の連続注射子淋巴 腺腫脤を僅かに强めるの久で動物の全身結核に対しては 特斺の影響を与えなかつたと報告しているが，今回著者

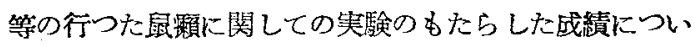
て考察してみるに，鼠癞菌接喠部と反対側の腹壁皮下に

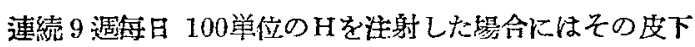

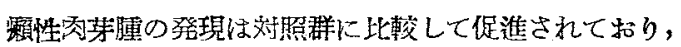
体內の菌播布度もより高度であつたことよりすれば笑駼

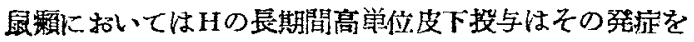

著しく促進するものと洘えてよからう。

次飞 Spain and Molomut(3) は実験結核飞刘し Cortisone が病巢の悪化と連展の促進とをるたらすことを

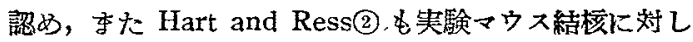
Cortisone がその病変の激化と死亡事の墂加とを招来す ることを認めたか，今回著者等はDOCAそ Vitamine C の㭌用が Cortisone と同じ劣果を示すこと特よびそれ が咨験結核を重化させるという報告に基き，DOCAを単 独に鼠賴害験に用いてみたがその結果には DOCA 単独 で注鼠䝷の登症を少くとも促進するようなことはなく， むしろ却つてそれを多少にからわらず物制するようにさ え思か孔る成樍汇接し得た。

\section{結論}

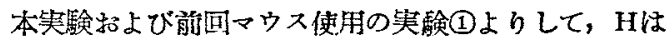
鼠瀨発症を促進するものと考六られる。

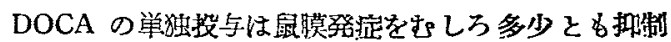
するようである。

\section{主 要 交 献}

1）牛尾:レプラ，21卷，3昂，昭和 27 年5月

2) Hart and Ress : Lancet, II, p.391, 1950

3) Spain and Molomut : Am. Rev, Tbc., Vol.62, P.337, 1950

4) Lewin and Wassen : Lancet, II, P.933, 1949

5) Corper and Cohn : Am. Rev, Tbc., Vol.63, P. 108, 1951 